43-44 | 2013

Le pastoralisme en Haute-Asie : la raison nomade dans l'étau des modernisations

\title{
Recent results from pastoralism research and development practice
}

Résultats récents de la recherche sur le pastoralisme et les pratiques de développement

\section{Hermann Kreutzmann}

\section{(2) OpenEdition}

Journals

Édition électronique

URL : https://journals.openedition.org/emscat/2017

DOI : 10.4000/emscat.2017

ISSN : 2101-0013

Éditeur

Centre d'Etudes Mongoles \& Sibériennes / École Pratique des Hautes Études

Référence électronique

Hermann Kreutzmann, « Recent results from pastoralism research and development practice ", Études mongoles et sibériennes, centrasiatiques et tibétaines [En ligne], 43-44 | 2013, mis en ligne le 20 septembre 2013, consulté le 13 juillet 2021. URL : http://journals.openedition.org/emscat/2017 ; DOI : https://doi.org/10.4000/emscat.2017

Ce document a été généré automatiquement le 13 juillet 2021.

(c) Tous droits réservés 


\title{
Recent results from pastoralism research and development practice
}

\author{
Résultats récents de la recherche sur le pastoralisme et les pratiques de \\ développement
}

Hermann Kreutzmann

\section{Approaches}

1 In conventional views, pastoralism was classified as a stage of civilisation that needed to be abolished and transcended in order to reach a higher level of development. At the same time interventions in pastoral spaces secured control over vast territories and unexplored resources. In this context, global approaches to modernize a rural society have been ubiquitous phenomena independent of ideological contexts. The $20^{\text {th }}$ century experienced a variety of concepts to sedentarise nomads and to transfer their lifestyles to modern perceptions. Permanent settlements have been the vivid expression of an ideology-driven approach. Modernisation theory captured all walks of life and subsequent development packages and programmes tried to optimize breeding techniques, pasture utilisation, transport and processing concepts. The aspect of input-outputoriented cost-efficiency tended to be neglected when the modernisation of animal husbandry was at stake according to a general purpose of increasing animal production yields.

2 New insights into other aspects of pastoralism such as its role as an adaptive strategy to use marginal resources in remote locations with difficult access could only be understood as a critique of capitalist and communist concepts of modernisation. The rejection of input-dominated theories that triggered enhancement of outputs but neglected ecological considerations regarding sustainability opened up a new field for research combining ecology, economy and society. This perception might gain further in importance when mitigation strategies coping with climate change and societal transformation are debated. 
3 Pastoralism can be perceived as a flexible strategy to adapt to changing survival conditions, rather than a transitory stage on the path to modern development only. Pastoralism was adopted by people when opportunities arose, when it was economically sound and when the challenges posed by ecological and socio-political environments could be managed.

4 Central Asia poses a unique arena for understanding the spectrum of mountain pastoralism and rangeland management. In a similar ecological environment of desertsteppe conditions, the cases of different communities can be compared in order to illustrate variegating paths of socio-economic and politico-historical developments that are the result of inner-communal dynamics and external interventions. The societal and political transformations during the $20^{\text {th }}$ century significantly modified the economic frame conditions, possibilities of political participation in decision-making processes, and cross-border exchange relations. Former commonalities among the studied communities have been transformed by inner-societal processes and by external linkages in response to decoupled exchange options.

5 The Tibetan Plateau is a huge ecological arena perfectly predisposed for mountain pastoralism. Debates about pastoral practices, common property regimes and rangeland management have gained pace in recent years since the environmental challenges and economic returns have been discussed in the framework of climate and global change. Initially the remote lifestyles of Tibetan nomads in peripheral regions were highlighted on account of sustenance from their own produce and subsistence economies. Even then mountain pastoralists were embedded in a network of mutual exchange relations that enabled them to survive in remote mountain plateaux and valleys. Their command of yak-breeding, their abilities to adapt to harsh environmental conditions and to cover huge distances between extensive natural pastures and market centres brought admiration from outside observers. Their "traditional lifestyle" seemed to be the perfect adaptation to environmental conditions.

6 Conventional thinking attributed more importance to ecological factors than to politics, economy and society. Thus, the focus was directed to local production and to grasslands situation and less to animal husbandry itself as one component of a mountain-based household production system. The $20^{\text {th }}$ century proved to be one of socio-economic change in all regions and for all communities. The Tibetan Plateau is no exception to this. Collectivisation in the aftermath of the Chinese Revolution introduced forms of social organisation that have been modified several times since. The shift from peoples' communes to the production responsibility system, from strict state governance and command economy to lenient forms of private ownership and entrepreneurship, from pasture laws to regulating rangeland management has introduced new concepts, policies and management tools that are significantly changing the institutional structure and organisational set-up.

7 The challenges are environmental degradation processes triggered by social and climate change, contested commons and their boundaries, external development and modernisation strategies versus local and regional perceptions and participation demands in decision-making processes. Present-day practices are the result of adaptive mechanisms as a response to all kinds of challenges and external reforms, infrastructure development and provision of subsidies. Mountain pastoral economies and societies of our time are strongly linked with neighbouring markets and interrelated socio-economic structures. This especially holds true for pastoralists of the 
Tibetan Plateau who are significantly embedded in government programmes and poverty alleviation strategies, and who respond to rangeland management packages and pasture laws by adapting to change. Their sources of income are highly diversified and draw on animal husbandry and agriculture as its basis and are augmented by government salaries, proceeds from wage labour and incomes from trade and entrepreneurship.

8 Today's mountain pastoralism is, on the one hand, a livestock-based activity and related to different localities connected through mobility. On the other hand, significant incomes are derived from other local and non-local sources, often surpassing the amount generated from pastoralism. In future, part of pastoralists' income may be derived from payment for ecological services that are provided by pastoralists as landscape managers for the maintenance of fragile environments and rewarding sustainable stocking practices. Pastoral practices reflect adaptive strategies that respond to the ecological, socio-economic and political environment over time, thus giving insights into path-dependent developments in remote mountain areas.

\section{Research and practice}

9 Similar ecological settings characterise the overall picture, nevertheless, external interventions have significantly influenced and shaped the welfare of mountain farmers and pastoralists alike. Over time spatial utilisation strategies have been transformed in accordance with the shift of political players and the replacement of stakeholders. Earlier patterns of evasion in the form of leaving spheres of influence in search of safer abodes have become approaches of limited success or have become overall inaccessible strategies. Consequently, adaptation to existing rules and acceptance of influential actors are observable patterns of mountain farmers and pastoralists in the Pamirian knot. In the majority of cases marginalisation in a shrinking space has occurred, although in a few cases living standards improved significantly. Modernisation has been a mixed blessing. Nevertheless, the path has been followed, and adjustments to it are the challenges of the present and the future. Classical mountain nomadism has only survived in Afghan environments, while the political transformations in the Soviet Union and the PR of China transformed pastoral strategies into a kind of detached mountain pastoralism. In both contexts the general adaptive strategy for utilizing high mountain pastures remained intact even after subsequent reforms and national independence. The socio-political context shifted to a stronger market orientation with higher degrees of differentiation among pastoralists and more degrees of freedom in decision-making. At the same time, less security is provided by state authorities.

\section{From state policy-driven production strategies to environmentalism : continuing modernisation in the pastoral world}

10 The "modernisation" argument remains to be addressed. Modernisation in a postSoviet, Afghan and/or Chinese context has a different meaning. The basic thinking might be along similar lines, but the expressions effecting development strategies, 
legislation and economic regulation differ significantly. China is an exception in regard to efficiency, investments and rigour when interfering in pastoralists' affairs. Central and South Asian societies in China's neighbourhood either are lacking the funds or are ignoring responsibilities for the pastoral world. Bhutan might be an exception in this regard. China's interventions in the form of "ecological migration", "sedentarisation" and "resettlement" seem to aim at a change in lifestyles. The welfare gap between affluent and middle-class urbanites and rural populations of the remote mountains and peripheral steppes has been widening. A society has to decide how to handle such a situation if the stipulated aim is to mitigate the effects of social differentiation. In affluent western societies substantial subsidies are regularly transferred as cash income to farmers and pastoralists in "disadvantaged regions". The public discourse has shifted over time. Presently, the protectors of cultural landscapes represent only a very small minority, but are in a comfortable position. Winds of change might bring a different sort of appreciation. Projected on the Tibetan Plateau, the question remains whether there is only one way forward. Critics of the resettlement schemes suggest that in contrast to a top-down approach a "community-co-management" could be helpful by incorporating local stakeholders, the pastoral households as local communities, as equal partners in a joint effort to design development packages that are accepted by all. Thus, valuable indigenous knowledge that regional planners nearly always lack could be made useful for tackling a complex constellation that calls for holistic and sensitive approaches. In any case, a decision-making process based on consensus supports acceptance, participation and understanding. For the future of the pastures on the Tibetan Plateau and in adjacent mountain regions this could be an exemplary model for reducing regional disparities by active support and structural exchange between affluent and disadvantaged areas.

11 In all other regions of concern more or less active strategies are pursued in the pastoral realm. Tajikistan and Kyrgyzstan are preparing and implementing new pasture laws. A herder's manual was recently released in cooperation with the University of Central Asia. All activities aim at preparing pastoralists for their adjustments in a transforming economic and ecological environment. India and Pakistan adopt legislation from their colonial past to adjust that legal framework to the challenges of international debates on climate change, forest and rangeland protection. Bhutan has identified pastoralists as landscape managers in remote locations and as valuable contributors to domestic food market. Nepal is participating in all international programmes and projects on offer, significant effects on the well-being of pastoralists and mountain farmers are difficult to be met with.

12 Overall the modernisation paradigm has been embedded in a climate change adaptation and mitigation scheme that in its ambiguity and vagueness very often hinders the identification of appropriate measures and useful development packages.

\section{Recent publications}

13 In the following a list of recent publications is attached. The list contains results from research as well as proceedings from international conferences that aimed at bridging the gap between academia, development practice and decision-making. The publications reflect the present state of debate and hint at the paradigms, development models and strategies presently applied. 


\section{BIBLIOGRAPHIE}

Agrawal, A. \& Saberwal, V. K.

2004 Whither South Asian pastoralism? An introduction, Nomadic Peoples 8, pp. 36-53.

Alden Wily, L.

2009 Recommended strategy for conflict resolution of competing high pasture claims of settled and nomadic communities in Afghanistan (Kabul, UNEP), 13 p.

Axelby, R.

2007 'It takes two hands to clap' : How Gaddi shepherds in the Indian Himalayas negotiate access to grazing, Journal of Agrarian Change 7(1), pp. 35-75.

Brower, B. \& Johnston, B. R. (eds.)

2007 Disappearing peoples? Indigenous Groups and Ethnic Minorities in South and Central Asia (Walnut Creek, Left Coast Press), $275 \mathrm{p}$.

Dangwal, D. D.

2009 The lost mobility. Pastoralism and modernity in Uttarakhand Himalaya (India), Nomadic Peoples 13(2), pp. 84-101.

Foggin, M. J.

2008 Depopulating the Tibetan Grasslands. National Policies and Perspectives for the Future of Tibetan Herders in Qinghai Province, China, Mountain Research and Development 28(1), pp. 26-31.

Gruschke, A.

2008 Nomads without pastures? Globalization, regionalization, and livelihood security of nomads and former nomads in Northern Khams, Journal of the International Association of Tibetan Studies 4, pp. 1-40.

Harris, R. B.

2010 Rangeland degradation on the Qinghai-Tibetan plateau : A review of the evidence of its magnitude and causes, Journal of Arid Environments 74, pp. 1-12.

Kreutzmann, H.

2011 Pastoral practices on the move. Recent transformations in mountain pastoralism on the Tibetan Plateau, in H. Kreutzmann, Y. Yang and R. Jürgen (eds.), Regional Workshop in Lhasa 2010. Pastoralism and rangeland management on the Tibetan Plateau in the context of climate and global change (Bonn, GIZ), pp. 200-224.

Kreutzmann, H. (ed.)

2012 Pastoral practices in High Asia. Agency of 'development' effected by modernisation, resettlement and transformation (Dordrecht, Springer), $350 \mathrm{p}$.

Kreutzmann, H. \& Schütte, S.

2011 Contested Commons - Multiple insecurities of pastoralists in North-Eastern Afghanistan, Erdkunde 65(2), pp. 99-119.

Kreutzmann, H., Kishwar, A., Lu, Z. \& Jürgen, R. (eds.)

2011 Regional workshop in Khorog and Kashgar. Pastoralism and rangeland management in mountain areas in the context of climate and global change (Bonn, GIZ), $214 \mathrm{p}$. 
Kreutzmann, H., Yang, Y. \& Jürgen, R. (eds.)

2011 Regional Workshop in Lhasa 2010. Pastoralism and rangeland management on the Tibetan Plateau in the context of climate and global change (Bonn, GIZ), $312 \mathrm{p}$.

Li, Wenjun, \& Lynn, Huntsinger

2011 China's grassland contract policy and its impacts on herder ability to benefit in Inner Mongolia : tragic feedbacks, Ecology and Society 16(2) : 1. [online] URL : http://

www.ecologyandsociety.org/vol16/iss2/art1/

Montero, R. Gil, Jon, M. \& Chetan, S. 2009 Mountain pastoralism 1500-2000 : An introduction Nomadic Peoples 13(2), pp. 1-16.

Nori, M., \& Davies, J.

2007 Change of wind or wind of change? Climate Change, Adaptation and Pastoralism. The World Initiative for Sustainable Pastoralism (Nairobi, IUCN), $12 \mathrm{p}$.

Ptackova, J.

2011 Sedentarisation of Tibetan nomads in China : Implementation of the nomadic settlement project in the Tibetan Amdo area ; Qinghai and Sichuan Provinces, Pastoralism. Research, Policy and Practice 1, pp. 4. http://www.pastoralismjournal.com/content/1/1/4.

Rahman, A., Duncan, A. J., Miller, D. W., Clemens, J., Frutos, P., Gordon, I. J., Rehman, A., Baig, A., Ali, F., \& Wright, I. A.

2008 Livestock feed resources, production and management in the agro-pastoral system of the Hindu Kush - Karakoram - Himalayan region of Pakistan : The effect of accessibility, Agricultural Systems 96, pp. 26-36.

Robinson, S. \& Whitton, M.

2010 Pasture in Gorno-Badakhshan, Tajikistan : common resource or private property?

Pastoralism 1(2), pp. 198-217.

Robinson, S., Whitton, M., Biber-Klemm, S. \& Muzofirshoev, N.

2010 The impact of land reform legislation on pasture tenure in Gorno-Badakhshan, Mountain Research and Development 30(1), pp. 4-13.

Steimann, B.

2011 Making a living in uncertainty. Agro-pastoral livelihoods and institutional transformations in postsocialist rural Kyrgyzstan. Human Geography Series 26 (Bishkek and Zurich, Department of Geography, University of Zurich), 245 p.

Tao Lu, Wu Ning \& Peng Luo

2009 Sedentarization of Tibetan nomads, Conservation Biology 23(5), pp. 1074.

Tapper, R.

2008 Who are the Kuchi ? Nomad self-identities in Afghanistan, Journal of the Royal Anthropological Institute 14, pp. 97-116.

Wilkes, A., Jingzheng Tan, Mandula

2010 The myth of community and sustainable grassland management in China, Frontiers of Earth Science in China 4(1), pp. 59-66.

Yamaguchi, T.

2011 Transition of Mountain Pastoralism : An agrodiversity analysis of the livestock population and herding strategies in Southeast Tibet, China, Human Ecology 39, pp. 141-154. 


\section{RÉSUMÉS}

Ces dernières années, un intérêt croissant a été accordé aux pratiques pastorales et à la recherche sur ce domaine. Deux raisons peuvent être avancées : d'abord une prise de conscience de l'importance des prairies et des pâturages dans un contexte de changement global, en particulier climatique. Ensuite, les différentes formes d'interventions extérieures sur les communautés pastorales modifient considérablement leurs degrés de liberté et contribuent à réduire l'espace dont elles disposent.

In recent years a growing attention is given to pastoralism research and practice. Two reasons are mainly responsible: First, the growing awareness of the importance of rangelands and pastures in the framework of global and climatic change. Second, the different forms of external interventions in the pastoral realm that have significantly changed the degrees of freedom and have contributed to a shrinking space for pastoral communities.

\section{INDEX}

Index géographique : Tibet

Mots-clés : pratiques pastorales modernisation, nomades, migration, sédentarisation

Keywords : pastoral practices, modernisation, nomads, migration, sedentarisation

\section{AUTEUR}

\section{HERMANN KREUTZMANN}

Hermann Kreutzmann is Chair of Human Geography and Director of the Institute of Geographic Sciences at the Freie Universitaet Berlin. Research subjects are human-environmental relations in South and Central Asia, high mountain research, pastoralism and hydraulic resources, development studies, migration research and political geography Publications :

2009 Transformations of High Mountain pastoral strategies in the Pamirian Knot, Nomadic Peoples, 13(2), pp. 102-123.

2008 Kashmir and the Northern Areas of Pakistan : Boundary-making along contested frontiers, Erdkunde 62(3), pp. 201-219.

2008 Dividing the World : Conflict and Inequality in the Context of Growing Global Tension, Third World Quarterly 29(4), pp. 675-689.

h.kreutzmann@fu-berlin.de 